Original Article

\title{
Proton pump inhibitors use and risk of chronic kidney disease: Evidence-based meta-analysis of observational studies
}

\author{
Salman Hussain ${ }^{\mathrm{a}}$, Ambrish Singh ${ }^{\mathrm{b}}$, Anwar Habib ${ }^{\mathrm{c}}$, Abul Kalam Najmi ${ }^{\mathrm{d}, *}$ \\ a Department of Pharmaceutical Medicine (Division of Pharmacology), School of Pharmaceutical Education and Research, Jamia Hamdard (Hamdard \\ University), New Delhi, 110062, India \\ ${ }^{\mathrm{b}}$ Independent Researcher, New Delhi, India \\ c Department of Medicine, Hamdard Institute of Medical Sciences and Research, Jamia Hamdard (Hamdard University), New Delhi, 110062, India \\ d Department of Pharmacology, School of Pharmaceutical Education and Research, Jamia Hamdard (Hamdard University), New Delhi, 110062, India
}

\section{A R T I C L E I N F O}

\section{Article history:}

Received 28 September 2017

Received in revised form 23 December 2017

Accepted 28 December 2017

Available online 29 December 2017

\section{Keywords:}

Chronic Kidney Disease

Proton Pump Inhibitor

Omeprazole

Systematic Review

Meta-analysis

\begin{abstract}
A B S T R A C T
Introduction: Proton pump inhibitors (PPIs) are one of the widely used drugs available as over the counter for treatment of acid-related gastrointestinal disorders. Concerns have been raised about the risk of developing chronic kidney disease (CKD) with the prolonged use of PPIs. This meta-analysis aims to determine the association between PPI use and risk of developing CKD.

Methods: The methodology complies with our registered protocol at PROSPERO (CRD42016040073). PubMed and Embase were searched from inception to 27th September 2017. Two reviewers independently screened and selected the observational studies comparing CKD outcome in patients on PPI. The quality of selected studies was assessed using Newcastle-Ottawa Scale. Subgroup and sensitivity analysis were also performed. All the analysis was performed by using RevMan v5.3.

Results: The 6 included studies comprised of 4 cohorts and 2 case-control studies with 720758 patients from cohort and 84078 patients from the case-control study. All the studies were of highest quality. Overall pooled relative risk (RR) of developing CKD was 1.32 (95\% CI 1.19 to 1.46$)$, ( $p$-value $=<0.00001$ ) and for end-stage renal disease (ESRD) RR was 1.88 (95\% CI: 1.71 to 2.07$),(p=<0.00001)$ in patients receiving PPI. The higher incidence of CKD was seen in diabetic patients taking PPI with RR of 1.82 (95\% CI 1.22 to 1.72 ), (p-value $=0.004$ ).

Conclusion: An association between proton pump inhibitor use and risk of developing chronic kidney disease and ESRD was found in the study.
\end{abstract}

(c) 2017 Published by Elsevier, a division of RELX India, Pvt. Ltd on behalf of INDIACLEN.

\section{Introduction}

Chronic Kidney Disease (CKD) or Chronic Renal Failure (CRF) is a long-term condition characterized by steady loss of kidney function over a period of time. ${ }^{1}$ CKD is a major global public health problem with prevalence $11-13 \%{ }^{2}$ It is more prevalent in the elderly population and is relatively more common in females. ${ }^{3}$ The high prevalence of CKD and increasing cost of long-term dialysis imparts a substantial economic burden on the healthcare systems across the globe. ${ }^{4}$ Furthermore, the poor health-related quality of life (HRQOL) due to declined physical functioning and comorbid conditions such as hypertension, anemia, ischemic heart disease, diabetes, and stroke results in increasing the societal

\footnotetext{
* Corresponding author at: Department of Pharmacology, School of Pharmaceutical Education and Research, Jamia Hamdard (Hamdard University), New Delhi, 110062, India.

E-mail address: aknajmi@jamiahamdard.ac (A.K. Najmi).
}

burden associated with CKD. ${ }^{5}$ As per the Global Burden of Disease study for the global cause of mortality in the year 2010, CKD jumped to the 18th rank from the original 27th rank in the year $1990 .^{6}$

Proton pump inhibitors (PPIs) introduced in the late $80 \mathrm{~s}$ are the class of drugs comprising omeprazole, esomeprazole, lansoprazole, pantoprazole, and others. ${ }^{7}$ Being one of the most widely used drugs worldwide, PPIs are the mainstay of gastroesophageal reflux disease (GERD) treatment. $^{8}$ Considering the acceptable safety profile, PPIs with over 113 million prescriptions and over-thecounter (OTC) sale, account for a market of $\$ 13$ billion globally. ${ }^{9}$ Additionally, the perceived favorable safety profile has contributed to significant over prescription with a reported $25-70 \%$ of PPIs prescribed without an appropriate indication. ${ }^{8-9}$ Despite an acceptable safety profile of PPIs, studies have linked them to adverse health outcomes including hip fracture, ${ }^{10}$ clostridium difficile infection, ${ }^{11}$ community-acquired pneumonia, ${ }^{12}$ acute kidney injury (AKI), ${ }^{13}$ and acute interstitial nephritis (AIN) ${ }^{14}$ 
Various studies have suggested the association between PPI use and the risk of developing renal complications; explicitly acute kidney disorders. ${ }^{15-17}$ Though the association between PPI exposure and acute kidney disease has been well studied, it is still unclear whether prolonged use of PPI is associated with the risk of developing CKD. Hence, this meta-analysis aimed to assess the association between PPI use and the risk of developing CKD.

\section{Methodology}

\subsection{Protocol}

This systematic review was conducted in accordance with the review protocol registered at the PROSPERO (Registration number: CRD42016040073). ${ }^{18}$ The meta-analysis was conducted in compliance with the PRISMA (Preferred Reporting Items for Systematic Reviews and Meta-Analysis) guidelines ${ }^{19}$ (Refer supplementary Table 1).

\subsection{Search Strategy}

PubMed and Embase electronic search engine were searched from inception to 27th September 2017 for studies assessing the risk of CKD in PPIs users. Keywords such as: proton pump inhibitors OR proton pump inhibitor* OR PPI* OR omeprazole OR lansoprazole OR dexlansoprazole OR esmoperazole OR pantoprazole OR rabeprazole OR ilaprazole AND chronic renal failure OR chronic kidney disease* OR chronic kidney failure OR chronic renal

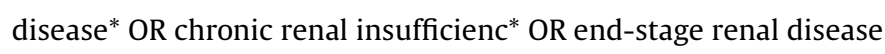
OR ESRD OR end-stage kidney disease OR ESKD were used to develop the search string. Hands-searching of the reference list of relevant articles was also done to find any additional appropriate article.

\subsection{Study Selection}

Two reviewers (SH and AS) independently screened the articles retrieved for potential inclusion using the title and abstract. Excel spreadsheet was used for screening of articles. Studies were included as per the pre-specified inclusion criteria detailed in the study protocol. ${ }^{18}$ Full-text articles selected on the basis of abstract and title were retrieved for further assessment and inclusion. The reviewers (SH and AS) independently screened the retrieved fulltext studies for final inclusion. In the case of disagreement over inclusion, the third reviewer (AKN) was consulted.

\subsection{Data extraction}

Full-text article of the included studies was examined and data were abstracted by two reviewers (SH and AS) independently using a standardized excel sheet. The information such as: (i) name of first author, publication year, and country; (ii) study design; (iii) number of subjects and CKD cases and size of the cohort; (iv) effect estimates and 95\% confidence intervals; (v) assessment of PPI exposure and assessment of CKD; (vi) control of confounding factors, if any; and other relevant information were abstracted.
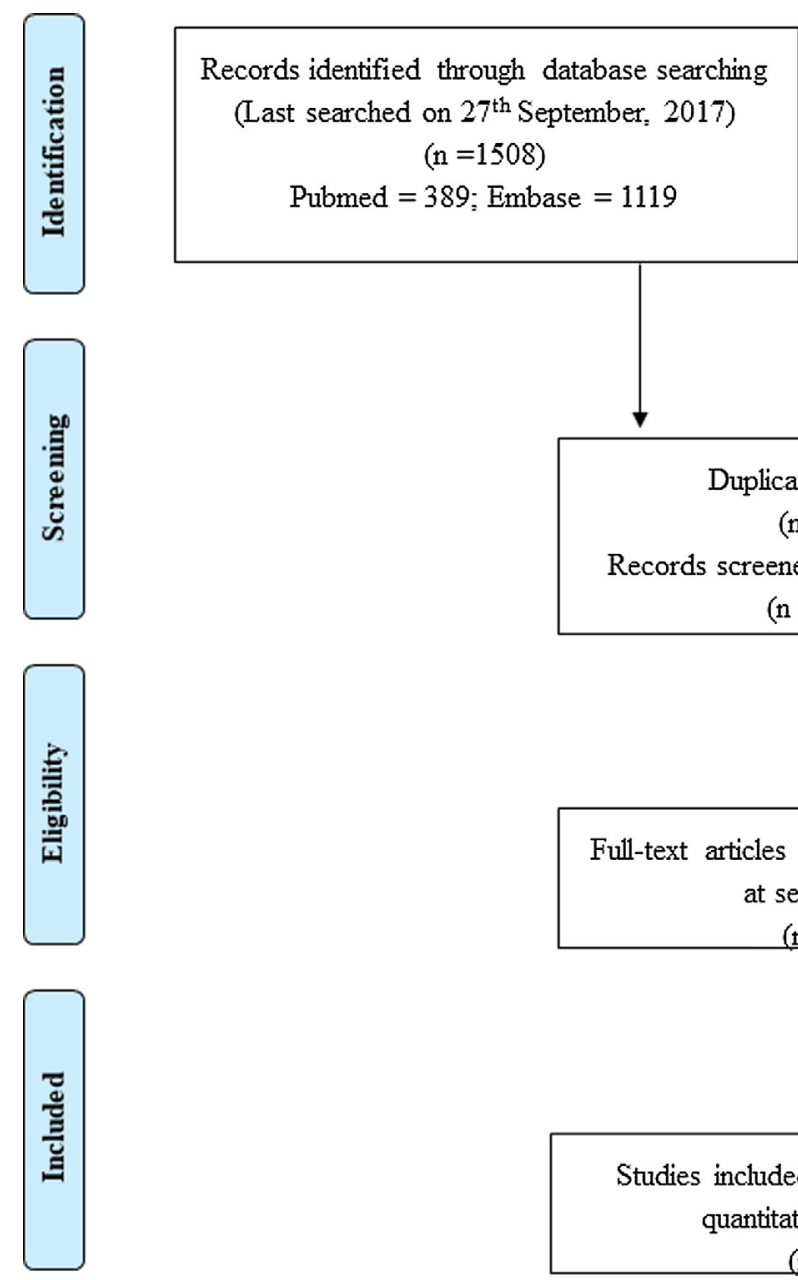

Duplicates removed

$(\mathrm{n}=153)$

Records screened (title and abstract)

$(\mathrm{n}=1355)$

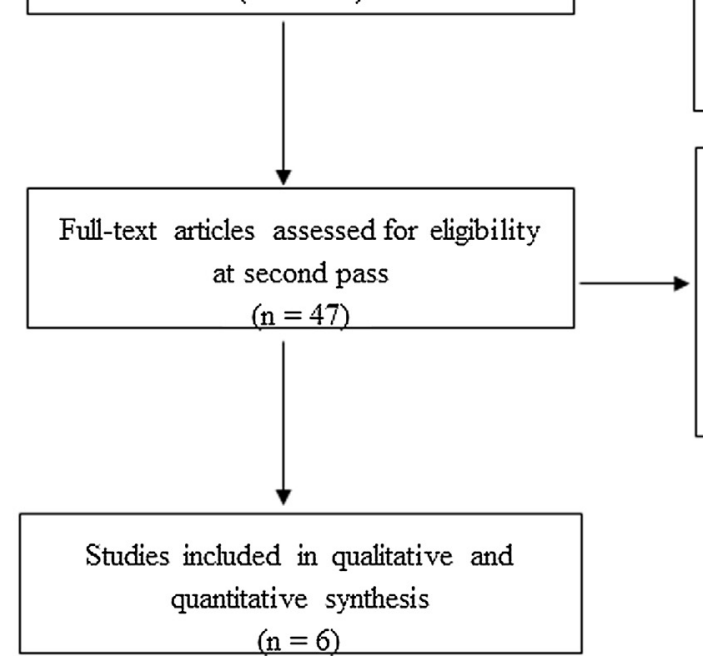

Full-text articles excluded, with

reasons $(n=41)$

Review $=11$

Not related to $\mathrm{CKD}=13$

Population not of interest $=10$

Outcome not of interest $=7$

Fig. 1. PRISMA flow diagram showing study selection process. 
Characteristics of included cohort studies.

\begin{tabular}{|c|c|c|c|c|c|c|c|c|c|c|c|c|c|c|c|}
\hline $\begin{array}{l}\text { Author, } \\
\text { Year }\end{array}$ & $\begin{array}{l}\text { Study } \\
\text { type }\end{array}$ & Country & Data source & $\begin{array}{l}\text { Study } \\
\text { Period }\end{array}$ & $\begin{array}{l}\text { Study } \\
\text { Follow- } \\
\text { up }\end{array}$ & $\begin{array}{l}\text { Incident chronic kidney disease } \\
\text { (CKD) definition }\end{array}$ & \% Men & $\begin{array}{l}\text { Mean Age } \\
\text { (Years) }\end{array}$ & $\begin{array}{l}\text { Total } \\
\text { sample }\end{array}$ & $\begin{array}{l}\text { No. of } \\
\text { PPI } \\
\text { users }\end{array}$ & $\begin{array}{l}\text { No of } \\
\text { CKD } \\
\text { cases } \\
\text { in PPI }\end{array}$ & $\begin{array}{l}\text { No. of } \\
\text { PPI } \\
\text { non- } \\
\text { users }\end{array}$ & $\begin{array}{l}\text { CKD } \\
\text { cases } \\
\text { in } \\
\text { non- } \\
\text { PPI }\end{array}$ & $\begin{array}{l}\text { Hazard } \\
\text { Ratio }\end{array}$ & Adjustment \\
\hline $\begin{array}{l}\text { Klatte } \\
\text { et al. } \\
2017^{25}\end{array}$ & Cohort & Sweden & $\begin{array}{l}\text { Stockholm } \\
\text { CREAtinine } \\
\text { Measurements } \\
\text { (SCREAM) } \\
\text { healthcare- } \\
\text { utilization } \\
\text { cohort study }\end{array}$ & 2006-2011 & 5 years & $\begin{array}{l}\text { Doubling of serum creatinine or } \\
\text { as }>30 \% \text { decline in eGFR }\end{array}$ & $39.7 \%$ & $\begin{array}{c}62.4(48.8- \\
73.8)^{*} \\
\text { (Interquartile } \\
\text { Range) years }\end{array}$ & 114883 & 105305 & 11045 & 9578 & 715 & $\begin{array}{l}1.26 \\
(1.16- \\
1.36)\end{array}$ & $\begin{array}{l}\text { Adjusted for age, sex, eGFR at baseline, } \\
\text { indications for acid-suppression } \\
\text { therapy, diabetes mellitus, } \\
\text { hypertension, peripheral vascular } \\
\text { disease, acute myocardial infarction, } \\
\text { cerebrovascular disease, congestive } \\
\text { heart } \\
\text { failure, chronic obstructive pulmonary } \\
\text { disease, NSAIDs, RAAS-inhibitors, beta } \\
\text { blockers, calcium channel blockers, } \\
\text { antithrombotics, } \\
\text { statins, and diuretics. }\end{array}$ \\
\hline $\begin{array}{l}\text { Larazus } \\
\text { et al. } \\
2016^{17}\end{array}$ & Cohort & US & $\begin{array}{l}\text { Atherosclerosis } \\
\text { Risk in } \\
\text { Communities } \\
\text { (ARIC) study }\end{array}$ & 1996-2011 & $\begin{array}{c}13.9 \\
\text { years }\end{array}$ & $\begin{array}{l}\text { Incident CKD was defined by } \\
\text { diagnostic codes that indicated } \\
\text { CKD at hospital discharge, or } \\
\text { death, or by incident ESRD. } \\
\text { (estimated glomerular filtration } \\
\text { rate of at least } 60 \mathrm{~mL} / \mathrm{min} / \\
1.73 \mathrm{~m}^{2} \text { ) }\end{array}$ & $43.90 \%$ & 63 years & 10482 & 322 & 56 & 10160 & 1382 & $\begin{array}{c}1.35 \\
(1.17- \\
1.55)\end{array}$ & $\begin{array}{l}\text { Adjusted for the age, sex, race, study } \\
\text { center, education, health insurance } \\
\text { status, baseline eGFR, ratio of urinary } \\
\text { albumin to creatinine, smoking status, } \\
\text { BMI, systolic blood pressure, diabetes } \\
\text { mellitus, cardiovascular disease, } \\
\text { antihypertensive medication use, and } \\
\text { anticoagulant medication use. }\end{array}$ \\
\hline $\begin{array}{l}\text { Larazus } \\
\text { et al. } \\
2016^{17}\end{array}$ & Cohort & US & $\begin{array}{c}\text { Geisinger } \\
\text { Health System } \\
\text { Replication } \\
\text { Cohort (GHSRC) } \\
\text { study }\end{array}$ & 1997-2014 & $\begin{array}{c}6.9 \\
\text { years }\end{array}$ & $\begin{array}{l}\text { Incident CKD was defined as the } \\
\text { first outpatient eGFR of less than } \\
\qquad 60 \mathrm{~mL} / \mathrm{min} / 1.73 \mathrm{~m}^{2}\end{array}$ & $43.44 \%$ & NR & 248751 & 16900 & 1921 & 231861 & 28226 & $\begin{array}{l}1.22 \\
(1.19- \\
1.25)\end{array}$ & $\begin{array}{l}\text { Adjusted for the age, sex, race, baseline } \\
\text { eGFR, smoking status, body mass } \\
\text { index, systolic blood pressure, diabetes } \\
\text { mellitus, cardiovascular disease, } \\
\text { antihypertensive medication use, } \\
\text { anticoagulant medication use, and } \\
\text { statin, aspirin use. }\end{array}$ \\
\hline $\begin{array}{l}\text { Xie et al. } \\
2016^{24}\end{array}$ & Cohort & US & $\begin{array}{l}\text { United States } \\
\text { Department of } \\
\text { Veterans Affairs } \\
\text { (VA) databases }\end{array}$ & $\begin{array}{l}\text { October } \\
\text { 2006- } \\
\text { September } \\
2008\end{array}$ & 5 years & $\begin{array}{l}\text { CKD defined as two } \\
\text { eGFRs, } 60 \mathrm{ml} / \mathrm{min} \text { per } 1.73 \mathrm{~m}^{2} \text { at } \\
\text { least } 90 \text { days apart. The first } \\
\text { measurement date considered } \\
\text { as date of CKD occurrence }\end{array}$ & $93.04 \%$ & 56.85 years & 346642 & 173321 & 26193 & 173321 & 17426 & $\begin{array}{c}1.28 \\
(1.22- \\
1.34)\end{array}$ & $\begin{array}{l}\text { Adjusted for baseline eGFR, age, race, } \\
\text { sex, diabetes mellitus, hypertension, } \\
\text { cardiovascular disease, peripheral } \\
\text { artery disease, cerebrovascular } \\
\text { disease, chronic lung disease, hepatitis } \\
\text { C, HIV, dementia, gastroesophageal } \\
\text { reflux disease, upper gastrointestinal } \\
\text { tract bleeding, ulcer disease, H. pylori } \\
\text { infection. }\end{array}$ \\
\hline
\end{tabular}

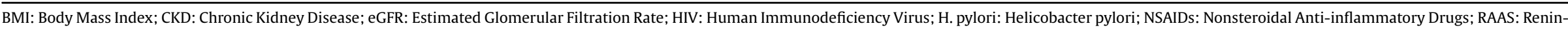
Angiotensin-Aldosterone System. 


\subsection{Quality assessment}

Quality assessment of all the included studies was performed by two reviewers ( $\mathrm{SH}, \mathrm{AH}$ ) independently. Newcastle-Ottawa Scale (NOS) is the most commonly used scale to judge the quality of observational studies specific to case-control and cohort studies. Thus, all the included studies were evaluated for quality using the NOS. NOS scale is divided into three major headings: selection, comparability, and exposure. Each study can obtain a maximum of one point for each numbered item within the selection and exposure categories. A maximum of two points can be given for comparability. Thus, each study can receive points between $0-9$. Based on the score on NOS scale, studies can be classified as: high quality (8-9 points), medium quality (6-7 points), and low quality $(<6$ points).

\subsection{Statistical analysis}

The primary outcome was to calculate the pooled risk ratio of all the included studies with 95\% confidence interval. The heterogeneity among the pooled studies was analyzed using Cochrane Q and I square statistics. Cochrane $\mathrm{Q}(p<0.10)$ or I square statistics value lie between 0 to $100 \%$, I square value $0-25 \%$ represents low heterogeneity, 25-50\% indicates moderate heterogeneity and values $>50 \%$ was considered as the presence of statistically significant heterogeneity. ${ }^{20}$ If significant heterogeneity noticed then random effect model applied over fixed effect model with an inverse variance method to calculate the pooled relative risk. Publication bias was assessed initially by visual inspection of the funnel plot and further confirmed by Egger's test. Duval and Tweedie nonparametric trim and fill method was applied if significant publication bias exists. Subgroup analysis was performed according to co-morbidity, follow-up period, study design, and gender to assess the factors responsible for heterogeneity among the studies in reporting risk ratios. We also performed the sensitivity analysis to ensure the robustness of results by excluding each study sequentially. All the analysis were performed using Review Manager (RevMan v5.3). ${ }^{21}$

\section{Result}

\subsection{Search result and study characteristics}

We identified 1508 records from the database search. After removing the duplicates and primary screening of title and abstract 1355 articles were retrieved, of which only six articles $^{22}, 17,23-25$ were found appropriate for inclusion after the secondary screening with full text. Bibliographic hand searching of the retrieved literature did not yield any additional article for inclusion. (Fig. 1).

Among the included articles $22,17,23-25$ Lazarus et al. ${ }^{17}$ has included two cohorts in his article namely Atherosclerosis Risk in Communities (ARIC) study and Geisinger Health System Replication Cohort (GHSRC) study. Hence, we considered four cohort studies and two case-control studies for inclusion with 720758 patients from cohort and 84078 patients from the casecontrol study. Studies were from the USA, ${ }^{22,17,24}$ Taiwan, ${ }^{23}$ and Sweden $^{25}$. All the studies published in the year 2016 except by Klatte et al. ${ }^{25}$ The follow-up period among studies ranged from 513.9 years. Tables 1 and 2 and present a detailed description of the characteristics of the included studies.

\subsection{Quality assessment}

All cohort ${ }^{17,24,25}$ and case-control study ${ }^{22,23}$ assessed for methodological quality on the NOS were found to be of high- quality, based on the scores attainment in: selection, comparability, and outcome parameters of NOS scale (Table 3 ).

\subsection{PPI use and risk of $C K D$}

Study conducted in Taiwan by Peng et al. ${ }^{23}$ has not reported the number of events, so the author was contacted to get the data for inclusion in the pooled analysis. Random effect model was applied over fixed effect model since significant heterogeneity was observed in the included studies $(\mathrm{p}=<0.00001$, I square $=95 \%$ ). Our study findings showed that the pooled RR of developing CKD was $1.32(95 \%$ CI 1.19 to 1.46$)$, ( $p$-value $=<0.0001)$ in PPI users as compared to non-PPI users (Fig. 2a).

\subsection{PPI use and risk of progression of kidney dysfunction and end- stage renal disease (ESRD)}

Three studies ${ }^{23-25}$ reported data for ESRD and two studies reported the data for $>30 \%$ decline in estimated glomerular filtration rate (eGFR) from the baseline. ${ }^{24,25}$ PPI use was significantly associated with the risk of developing ESRD with a pooled RR of 1.88 (95\% CI: $1.71-2.07),(p=<0.00001$, I square $=0 \%)$ (Fig. 2b). PPI use was also significantly associated for risk of progression of kidney dysfunction as determined by declining in eGFR by $>30 \%$ [RR 1.30 (95\% CI 1.25-1.36), ( $p$-value $=<0.0001$, I square $=0 \%$ ).

\subsection{Subgroup analysis}

In subgroup analysis based on the gender, no significant association was observed for the PPI use and risk of CKD among male and female. Studies reporting the follow-up period $>5$ years were categorized under long-term follow-up study. Based on the duration of exposure, the RR of developing the CKD was found to be highly significant for long-term exposure 1.20 (95\% CI 1.10 to 1.31 ), $(p$-value $=0.92$ ). Based on study design the, pooled data from cohort studies showed the RR of CKD in PPI user to be 1.24 (95\% $\mathrm{CI}=1.21$ to 1.26$)$, $(p$-value $=<0.00001)$, whereas for the casecontrol study it was 1.44 (95\% CI 1.16 to 1.80$)$, ( $p$-value $=0.18)$. A detailed description is presented in Table 4. Subgroup analysis was also performed based on the disease status. We found the statistically significant deteriorative effect of PPI use in a diabetic population with a pooled RR of 1.82 (95\% CI 1.22-2.72), ( $p$ value $=0.004)$ (Fig. 3$)$. We also assessed the effect of concomitant drug use. The pooled estimate of PPI user with ACE-I/ARB compared to only PPI user did not show any significant association for the development of CKD. Pooled estimate showed significant association for the CKD in PPI diuretic users as compared to only PPI users [RR $2.29(95 \%$ CI 2.09-2.50)], $(p$-value $=<0.00001)$ [two studies- ARIC \& GHSRC cohort $\left.^{17}\right]$.

\subsection{Sensitivity analysis}

Each study was sequentially excluded to assess the robustness of the pooled risk ratio. Exclusion of any of the specific studies did not demonstrate any alteration in the results as evident from the sensitivity analysis.

\subsection{Publication bias}

Visual inspection of funnel plot did not suggest the presence of publication bias, which was further confirmed by Egger's test $(\mathrm{p}=0.59)$. 
Table 2

Characteristics of included case-control studies.

\begin{tabular}{|c|c|c|c|c|c|c|c|c|c|c|c|c|c|c|}
\hline $\begin{array}{l}\text { Author, } \\
\text { Year }\end{array}$ & $\begin{array}{l}\text { Study } \\
\text { type }\end{array}$ & Country & Data source & $\begin{array}{l}\text { Study } \\
\text { Period }\end{array}$ & Study Follow-up & Patient setting & \% Men & $\begin{array}{l}\text { Total } \\
\text { no of } \\
\text { PPI } \\
\text { user }\end{array}$ & \multicolumn{2}{|c|}{$\begin{array}{l}\text { No. of cases } \\
\text { (CKD) }\end{array}$} & \multicolumn{2}{|c|}{$\begin{array}{l}\text { No. of controls } \\
\text { (Non-CKD) }\end{array}$} & $\begin{array}{l}\text { Hazard } \\
\text { Ratio }\end{array}$ & Adjustment \\
\hline $\begin{array}{c}\text { Peng et al. } \\
2016^{23}\end{array}$ & $\begin{array}{l}\text { Case- } \\
\text { control }\end{array}$ & Taiwan & $\begin{array}{l}\text { Taiwan } \\
\text { National } \\
\text { Health } \\
\text { Insurance } \\
\text { Research } \\
\text { Database, } \\
\text { (LHID 2000) } \\
\text { and RCIPD }\end{array}$ & $\begin{array}{c}2006- \\
2011\end{array}$ & $\begin{array}{c}\text { Case group } \\
(\text { ESRD) } \\
3.99 \pm 3.46 \\
\text { years Control } \\
\text { group } \\
4.02 \pm 3.04 \text { years }\end{array}$ & $\begin{array}{c}\text { Renal disease } \\
\text { patients } \\
\text { (age } \geq 20 \text { years) }\end{array}$ & $52.20 \%$ & 7616 & $\begin{array}{l}\text { Total: } \\
\text { PPI } \\
2647\end{array}$ & $\begin{array}{c}3808 \\
\text { Non- } \\
\text { PPI } \\
1161\end{array}$ & $\begin{array}{l}\text { Total } \\
\text { PPI } \\
2102\end{array}$ & $\begin{array}{c}3808 \\
\text { Non- } \\
\text { PPI } \\
1706\end{array}$ & $\begin{array}{c}1.88 \\
(1.71- \\
2.06)\end{array}$ & $\begin{array}{l}\text { Adjusted for } \\
\text { gender, age, } \\
\text { calcium } \\
\text { channel } \\
\text { blocker, } \\
\text { diabetes, and } \\
\text { hypertension. }\end{array}$ \\
\hline $\begin{array}{l}\text { Arora } \\
\text { et al. } \\
2016^{22}\end{array}$ & $\begin{array}{l}\text { Case- } \\
\text { control }\end{array}$ & US & $\begin{array}{c}\text { Veterans } \\
\text { Affairs Health } \\
\text { Care Upstate } \\
\text { New York } \\
\text { (VISN2) } \\
\text { database }\end{array}$ & $\begin{array}{l}2001- \\
2008\end{array}$ & 7 years & $\begin{array}{l}\text { Cases are the } \\
\text { patient with } \\
\text { eGFR }>60 \mathrm{ml} / \\
\mathrm{min} / 1.73 \mathrm{~m} 2\end{array}$ & $\begin{array}{c}\text { Not } \\
\text { reported }\end{array}$ & 22734 & $\begin{array}{r}\text { No. o } \\
(\mathrm{Cl} \\
19 \\
\text { PPI } \\
4711\end{array}$ & $\begin{array}{l}\text { cases } \\
\text { KD) } \\
311 \\
\text { Non- } \\
\text { PPI } \\
14600\end{array}$ & $\begin{array}{r}\text { No. of } \\
\text { (Non } \\
57 \\
\text { PPI } \\
\\
18023\end{array}$ & $\begin{array}{l}\text { ontrols } \\
\text { CKD) } \\
51 \\
\text { Non- } \\
\text { PPI } \\
39128\end{array}$ & $\begin{array}{c}1.10 \\
(1.04- \\
1.16)\end{array}$ & $\begin{array}{l}\text { Controlling for } \\
\text { age, sex, race, } \\
\text { GI and pre-PPI } \\
\text { comorbidities }\end{array}$ \\
\hline
\end{tabular}

ESRD: End Stage Renal Disease; CKD: Chronic Kidney Disease; eGFR: Estimated Glomerular Filtration Rate; US: United States.

Table 3

Quality assessment of the study by using NewCastle-Ottawa scale.

\begin{tabular}{|c|c|c|c|c|c|}
\hline Study & Selection & Comparability & Outcome & Total score & Quality of the study \\
\hline Klatte et al. $2017^{25}$ & $* * * *$ & $* *$ & $* * *$ & 9 & High quality \\
\hline Lazarus et al. 2016 (ARIC) ${ }^{17}$ & $* * * *$ & $* *$ & $* * *$ & 9 & High quality \\
\hline Lazarus et al. 2016 (GHSRC) $^{17}$ & $* * *$ & $* *$ & $* * *$ & 8 & High quality \\
\hline Xie et al. $2016^{24}$ & $* * * *$ & $* *$ & $* * *$ & 9 & High quality \\
\hline Arora et al. $2016^{22}$ & $* * * *$ & $* *$ & $* * *$ & 9 & High quality \\
\hline Peng et al. $2016^{23}$ & $* * * *$ & $* *$ & $* * *$ & 9 & High quality \\
\hline
\end{tabular}

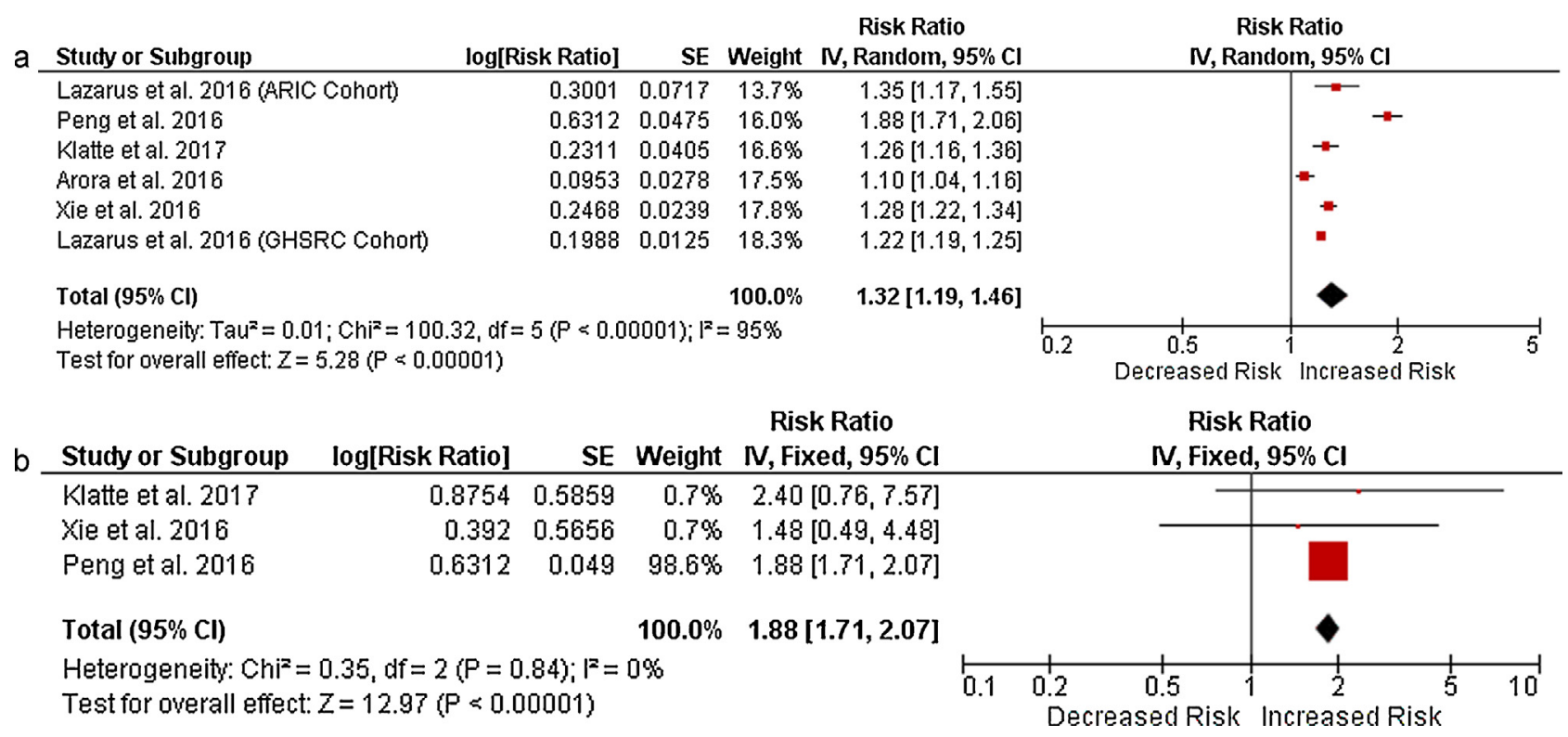

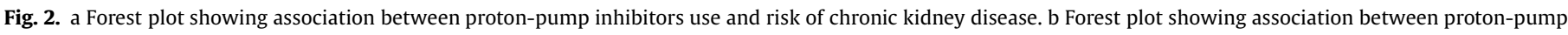
inhibitors use and risk of ESRD.

\section{Discussion}

In this systematic review and meta-analysis, we set out to examine the risk of CKD with the use of PPI. The studies identified by this systematic review and analysed by the meta-analysis demonstrate that PPI use appears to be associated with significant elevated risk of developing CKD in PPI users compared to the nonPPI users (pooled RR $=1.32(95 \%$ CI 1.19-1.46), $(p$-value $=<0.0001)$.
The associations are independent of gender; however diabetic PPI user population are at higher risk of developing CKD compared to non-PPI users as seen in the subgroup analysis.

PPIs are one of the most common causes of drug-induced acute interstitial nephritis (AIN) worldwide. ${ }^{26-27}$ Though the exact mechanism by which PPIs induce AIN is still to be explained, it is postulated that the metabolites of PPIs may deposit inside the tubulointerstitium of the kidney to directly stimulate T-cells or act 
Table 4

Overall effect estimates for chronic kidney disease and proton pump inhibitors use according to subgroups.

\begin{tabular}{|c|c|c|c|c|c|}
\hline Characteristics & Number of studies & RR (95\% CI) & $p$-value & Cochrane Q & $\mathrm{I}^{2}$ \\
\hline \multicolumn{6}{|l|}{ Gender } \\
\hline Male & 3 & $1.03(0.84-1.28)$ & 0.77 & 58.40 & $95 \%$ \\
\hline Female & 3 & $1.03(0.98-1.09)$ & 0.24 & 4.45 & $33 \%$ \\
\hline \multicolumn{6}{|l|}{ Study Design } \\
\hline Cohort & 4 & $1.24(1.21-1.26)$ & $<0.00001$ & 4.96 & $40 \%$ \\
\hline Case-control & 2 & $1.44(0.85-2.43)$ & 0.18 & 94.81 & $99 \%$ \\
\hline \multicolumn{6}{|l|}{ Follow-up } \\
\hline Long term & 3 & $1.20(1.10-1.31)$ & $<0.0001$ & 14.20 & $86 \%$ \\
\hline Short term & 3 & $1.44(1.16-1.80)$ & 0.001 & 56.42 & $96 \%$ \\
\hline
\end{tabular}

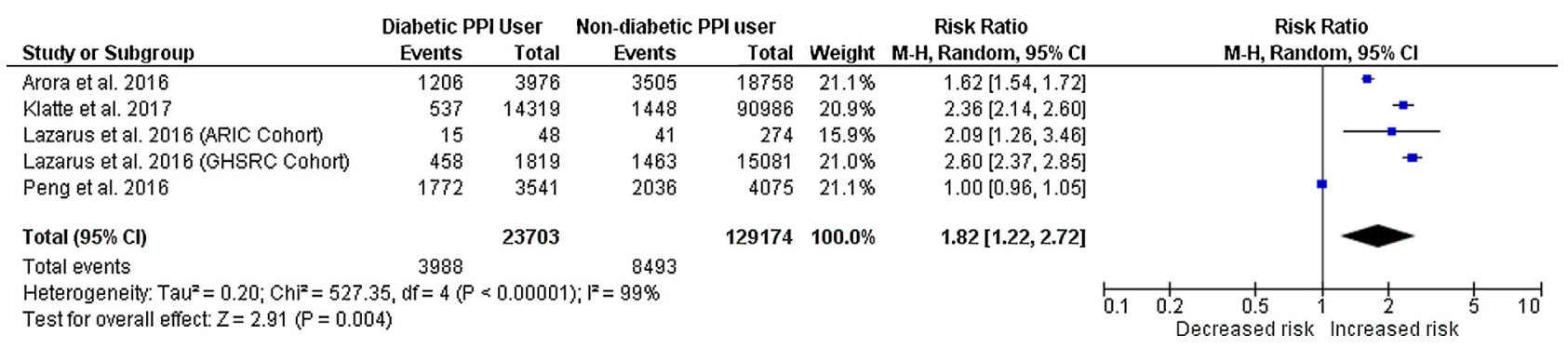

Fig. 3. Pooled risk ratio of CKD in diabetic PPI user as compared to non-diabetic PPI user.

as either a hapten to mediate AIN. ${ }^{28}$ PPIs were first identified to have a causal relationship with AIN and acute renal injury in the year $1992 .{ }^{28}$ In 2006 Simpson et al. ${ }^{29}$ in a case series reported the incidence of AIN to be 8.0 per 100,000 person-years (95\% CI $2.6-$ 18.7); similar results were reported by Blank et al. ${ }^{15}$ in a casecontrol study. While Simpson et al. ${ }^{29}$ reported a partial recovery of renal function after PPI-induced AIN, Geevasinga et $a .^{30}$ in a separate case series in the same year reported that in 18 PPIinduced AIN cases patients recovered the renal function, however, the mean calculated creatinine clearance was lower than baseline at 3 and 6 months. The impairing effect of PPIs on the renal function is also one of the possible explanation for its ill effect on kidney and hence CKD. ${ }^{31}$ Furthermore, in patients with PPIinduced AIN, early diagnosis and withdrawal of PPI are often jeopardised by that fact that, roughly $10 \%$ of the patients manifest classic triad of hypersensitivity reactions (i.e. fever, rash, and eosinophilia). ${ }^{25}$ Furthermore, in a recent systematic review and meta-analysis by Xie et al. $^{32}$ the patient on PPI therapy were found to be at increased risk of chronic renal outcomes even in the absence of intervening AKI.

This systematic review found that the PPI user with pre-existing diabetes was more likely to develop CKD compared to the similar non-PPI users diabetic population. Diabetes is a well-established risk factor for the kidney disease with $\sim 30 \%$ of the patients with type 1 diabetes and $10-40 \%$ of those with type 2 diabetes predisposed kidney failure. ${ }^{33}$ In diabetic population hyperfiltration injury, advanced glycosylation end products, and reactive oxygen species are found to be a responsible mechanism for kidney disease. ${ }^{34}$

In the process of study selection, we observed that the study conducted by Lazarus et al. ${ }^{17}$ had included cohort from two different databases namely, ARIC and GHSRC. Hence, we considered them as an independent cohort and analysed accordingly. The strength of this review includes: protocol oriented approach, ${ }^{18}$ an exhaustive search of two major bibliographic databases, and hand searching of the relevant articles. Although most of the included studies were of high quality as reflected by the quality assessment scores, this meta-analysis had some limitations. Hence, the results should be interpreted with caution. The notable limitations of this review are: the heterogeneity among selected studies, in terms of the follow-up duration, dose of PPI therapy, and study quality assessed on NOS. The heterogeneity assessment, the pooled effects estimate, and the publication bias of the studies may be imprecise since the number of included studies reporting on PPI exposure and risk of CKD was small. ${ }^{20}$ Furthermore, to be noted, funnel plot is thought to be unreliable methods of investigating publication bias, particularly if the number of included studies is small. ${ }^{35}$ Also as a meta-analysis of observational studies with significant heterogeneity, this systematic review could only demonstrate an association and has its own limitation in establishing the causality.

\section{Conclusion}

This meta-analysis demonstrated an increased risk of CKD and ESRD among the PPIs users. However, pertaining to the inherent limitations in methodology and heterogeneity of the included studies, the results should be interpreted accordingly.

\section{Funding}

None.

\section{Conflict of interest}

Authors declare that they have no conflict of interest.

\section{Meeting Presentation}

This paper (abstract) was accepted for poster presentation at the 54th ERA-EDTA Congress, Madrid, Spain, June 3rd-6th 2017. 


\section{Acknowledgements}

First author ( $\mathrm{SH}$ ) thankful to Sun Pharmaceuticals, India, for providing assistantship for this project under the joint collaboration for the Ph.D. programme with Jamia Hamdard, Hamdard University, New Delhi, India.

\section{Appendix A. Supplementary data}

Supplementary data associated with this article can be found, in the online version, at https://doi.org/10.1016/j.cegh.2017.12.008.

\section{References}

1. About chronic kidney disease. Available at: https://www.kidney.org/atoz/ content/about-chronic-kidney-disease. (Accessed 15 September 2017).

2. Hill NR, Fatoba ST, Oke JL, Hirst JA, O'Callaghan CA, Lasserson DS, et al. Global prevalence of chronic kidney disease?a systematic review and meta-analysis. PLoS One. 2016;11(7):e0158765.

3. National chronic kidney disease fact sheet. Available at: https://www.cdc.gov/ diabetes/pubs/pdf/kidney_factsheet.pdf. (Accessed 15 September 2017).

4. Couser WG, Remuzzi G, Mendis S, Tonelli M. The contribution of chronic kidney disease to the global burden of major noncommunicable diseases. Kidney Int. 2011;80(12):1258-1270.

5. Mujais SK, Story K, Brouillette J, Takano T, Soroka S, Franek C, et al. Healthrelated quality of life in CKD patients: correlates and evolution over time. Clin J Am Soc Nephrol. 2009;4(8):1293-1301.

6. Lozano R, Naghavi M, Foreman K, Lim S, Shibuya K, Aboyans V, et al. Global and regional mortality from 235 causes of death for 20 age groups in 1990 and 2010: a systematic analysis for the Global Burden of Disease Study 2010. Lancet. 2012;380(9859):2095-2128.

7. Mullin JM, Gabello M, Murray LJ, Farrell CP, Bellows J, Wolov KR, et al. Proton pump inhibitors: actions and reactions. Drug Discov Today. 2009;14(1314):647-660.

8. Forgacs I, Loganayagam A. Overprescribing proton pump inhibitors. BMJ. 2008;336(7634):2-3.

9. Savarino V, Dulbecco P, de Bortoli N, Ottonello A, Savarino E. The appropriate use of proton pump inhibitors (PPIs): need for a reappraisal. Eur J Intern Med. 2017;37:19-24.

10. Hussain S, Najmi AK, Anil D. Proton pump inhibitors use and risk of hip fracture: a meta-analysis of observational studies. Osteoporos Sarcopenia. 2017;3(3):S4510.1016/j.afos.2017.08.086.

11. Pohl JF. Clostridium difficile infection and proton pump inhibitors. Curr Opin Pediatr. 2012;24(5):627-631.

12. Lambert AA, Lam JO, Paik JJ, Ugarte-Gil C, Drummond MB, Crowell TA. Risk of community-acquired pneumonia with outpatient proton-pump inhibitor therapy: a systematic review and meta-analysis. PLoS One. 2015;10(6): e0128004.

13. Antoniou T, Macdonald EM, Hollands S, Gomes T, Mamdani MM, Garg AX, et al. Proton pump inhibitors and the risk of acute kidney injury in older patients: a population-based cohort study. CMAJ Open. 2015;3(2):E166-E171.
14. Sierra F, Suarez M, Rey M, Vela M. Systematic review: proton pump inhibitorassociated acute interstitial nephritis. Aliment Pharmacol Ther. 2007;26 (4):545-553.

15. Blank M-L, Parkin L, Paul C, Herbison P. A nationwide nested case-control study indicates an increased risk of acute interstitial nephritis with proton pump inhibitor use. Kidney Int. 2014;86(4):837-844.

16. Klepser DG, Collier DS, Cochran GL. Proton pump inhibitors and acute kidney injury: a nested case-control study. BMC Nephrol. 2013;14:150.

17. Lazarus B, Chen Y, Wilson FP, Sang Y, Chang AR, Coresh J, et al. Proton pump inhibitor use and the risk of chronic kidney disease. JAMA Intern Med. 2016;176 (2):238-246.

18. Hussain S, Singh A, Najmi AK. Proton pump inhibitors use and the risk of chronic kidney disease: a systematic review. PROSPERO; 2016 CRD42016040073 Available from: https://www.crd.york.ac.uk/prospero/display_record.asp? ID=CRD42016040073.

19. Moher D, Shamseer L, Clarke M, Ghersi D, Liberati A, Petticrew M, et al. Preferred reporting items for systematic review and meta-analysis protocols (PRISMA-P) 2015 statement. Syst Rev. 2015;4:1.

20. Higgins JP, Green S. Cochrane Handbook for Systematic Reviews of Interventions. John Wiley \& Sons; 2011.

21. Review Manager (RevMan) [Computer program]. Version5.3. Copenhagen: The Nordic Cochrane Centre, The Cochrane Collaboration; 2014

22. Arora P, Gupta A, Golzy M, Patel N, Carter RL, Jalal K, et al. Proton pump inhibitors are associated with increased risk of development of chronic kidney disease. BMC Nephrol. 2016;17(1):112.

23. Peng YC, Lin CL, Yeh HZ, Chang CS, Wu YL, Kao CH. Association between the use of proton pump inhibitors and the risk of ESRD in renal diseases: a populationbased, case-control study. Medicine (Baltimore). 2016;95(15):e3363.

24. Xie Y, Bowe B, Li T, Xian H, Balasubramanian S, Al-Aly Z. Proton pump inhibitors and risk of incident CKD and progression to ESRD. J Am Soc Nephrol. 2016;27 (10):3153-3163.

25. Klatte DCF, Gasparini A, Xu H, de Deco P, Trevisan M, Johansson ALV Association between proton pump inhibitor use and risk of progression of chronic kidney disease. Gastroenterology. 2017;153(3):702-710.

26. Brewster U, Perazella M. Proton pump inhibitors and the kidney: critical review. Clin Nephrol. 2007;68(2):65-72.

27. Moledina DG, Perazella MA. PPIs and kidney disease: from AIN to CKD. J Nephrol. 2016;29(5):611-616.

28. Ruffenach SJ, Siskind MS, Lien Y-HH. Acute interstitial nephritis due to omeprazole. Am J Med. 1992;93(4):472-473.

29. Simpson IJ, Marshall MR, Pilmore H, Manley P, Williams L, Thein H, et al. Proton pump inhibitors and acute interstitial nephritis: report and analysis of 15 cases. Nephrology (Carlton). 2006;11(5):381-385.

30. Geevasinga N, Coleman PL, Webster AC, Roger SD. Proton pump inhibitors and acute interstitial nephritis. Clin Gastroenterol Hepatol. 2006;4(5):597-604.

31. Lodato F, Azzaroli F, Turco L, Mazzella N, Buonfiglioli F, Zoli M, et al. Adverse effects of proton pump inhibitors. Best Pract Res Clin Gastroenterol. 2010;24 (2):193-201.

32. Xie Y, Bowe B, Li T, Xian H, Yan Y, Al-Aly Z. Long-term kidney outcomes among users of proton pump inhibitors without intervening acute kidney injury. Kidney Int. 2017;91(6):1482-1494.

33. Harjutsalo V, Groop PH. Epidemiology and risk factors for diabetic kidney disease. Adv Chronic Kidney Dis. 2014:21(3):260-266.

34. Lea JP, Nicholas SB. Diabetes mellitus and hypertension: key risk factors for kidney disease. J Natl Med Assoc. 2002;94(8 Suppl):7S-15S.

35. Sedgwick P, Marston L. How to read a funnel plot in a meta-analysis. BMJ. 2015;351:h4718. 